\title{
Thematic Lessons from the Marikana Miners' Strike in South Africa: A Corporate Governance Perspective
}

\author{
Linda Muswaka \\ Lecturer, Faculty of Law, North West University - South Africa \\ E-mail: leemuswaka@gmail.com
}

Doi:10.5901/mjss.2014.v5n2p63

\begin{abstract}
The Marikana's miners' strike began on 10 August with the demand by approximately three thousand rock drillers to have salaries increased from R4 000,00 per month to R12 500,00 per month. These workers walked off the job after Lonmin management failed to meet with workers. A series of violence then followed leading to the massacre that occurred on 16 August when at least thirty six miners were killed and seventy eight wounded by members of the South African Police Service (SAPS). Following this incident, the President of the Republic of South Africa, Mr. Jacob Zuma appointed, in terms of section 84(2)(f) of the Constitution of the Republic of South Africa, 1996 a Commission of Inquiry chaired by retired Judge of the Supreme Court of Appeal, Ian Gordon Farlam. The Commission's mandate arising from the Terms of Reference promulgated on 12 September 2012 is to investigate matters of public, national and international concern arising out of the tragic incidents at the Lonmin Platinum mine in Marikana. This article examines the Marikana miners' strike through corporate governance lens. The aim is to extract thematic lessons from a corporate governance perspective.
\end{abstract}

Keywords: Corporate Governance, Shareholders, Stakeholders, Marikana, Mine workers, Mining Communities

\section{Introduction}

The Marikana miners' strike, though initially perceived as a wage strike by the mining workers appears to have been a climax of the more problems the workers experienced in the mining sector as a result of the corporate governance approach that is shareholder value oriented and fails to adequately consider the interests of other stakeholders such as the mine workers and the mining communities. In the aftermath of the Marikana massacre, the Department of Trade and Industry Minister, Mr. Rob Davies described the conditions in the mines as appalling and stated that the mining companies who make millions had questions to answer about how they treat their workers. ${ }^{1}$ The International Labour Organization ${ }^{2}$ also criticized the working conditions of the miners saying they are exposed to a variety of safety hazards such as falling rocks, exposure to dust, intensive noise, fumes and high temperatures, amongst others. ${ }^{3}$ These observations points to the danger of shareholder value oriented corporate governance.

Shareholder value oriented corporate governance requires a company to be run in such a way as to maximize the interests of the shareholders ahead of the interests of any other stakeholders. In terms of this view, a director has no general duty to consider the interests of stakeholders. Obviously directors are allowed to consider the interests of stakeholders and sometimes good management will require this, but ultimately the interests of stakeholders are subordinate to those of the shareholders. While the shareholder value approach has often been taken for granted it is increasingly being questioned. There is pressure on companies and directors to take into account not only the shareholders when they manage a company, but rather the interests of all stakeholders.

This article examines the Marikana miners' strike through corporate governance lens. The strike raise concerns on the shareholder value oriented corporate governance as it reveals the harsh realities being faced by stakeholders such as the mine workers and the communities in which the mining companies operates. It will be argued that the Marikana miners' strike reinforces the argument for stakeholder oriented corporate governance. Consequently, thematic lessons

1 Corporate Watch, "Blood Money, Shock Revelations and Media Half-Truths on South African Mine Violations" (2013) available at http://www.corporatewatch.org/?lid=4741, accessed on 25 March 2013.

2 Hereafter, the ILO.

3 See The ILO news, available at http://www.ilo.org/global/about-the-lo/newsroom/news/WCMS_187783/lang --en/index.htm, accessed on 22 January 2013. The ILO mining specialist Martin Hahn stated that while South Africa has taken significant steps since the end of apartheid to address working conditions in the mining industry, there is still a lot of room for improvement. 
are extracted from the strike, from a corporate governance perspective.

\section{Background of Mining in South Africa}

Historically, mining has been central to the South African economy. ${ }^{4}$ The structure of the South African economy, whereby the mineral and energy complex is the main driver of the economy, first emerged out of the discovery of gold and diamonds in the late nineteenth century. South Africa holds a major economic and physical presence on the African continent and the world at large regarding mining. About a quarter of South Africa's exports come from mining. South Africa ranks number five in the world in gold production. ${ }^{5} \mathrm{It}$ is the largest producer of platinum in the world. ${ }^{6} \mathrm{It}$ produces $80 \%$ of the world's platinum. ${ }^{7}$ Mining has been the mainstay of the economy and has contributed significantly to the industrial development of the country. ${ }^{8}$ In the past 10 years, the development of export-oriented value-added processing aluminium, ferro-alloys, steel, and titanium industries has become an important component of the mineral economy of South Africa. ${ }^{9}$ The development of these value-added industries along with an expansion in coal exports and an increase in Platinum Group Metals prices has helped compensate for the declining contribution of gold in the economy. ${ }^{10}$

\section{The Marikana's Miners' Strike}

The expansion of the mining companies in South Africa was driven inter alia by the availability of the supply of cheap labour that ensured that healthy profit margins could be attained. During the twentieth century mineworkers epitomized apartheid's oppression and exploitation of black labour. Thousands of miners died in work-related incidents during the pre-1994 era. Mineworkers were cheap, migrant black workers drawn not only from the hinterlands of South Africa but from the entire region, from countries such as Botswana, Malawi, Mozambique, Zambia and Zimbabwe. Post-1994, nothing much has changed for the mine workers who are still being paid appalling wages as evidenced by the Marikana miners' strike.

The strike began with the demand by approximately three thousand rock drillers to have salaries increased from R4 000 per month to R12 500 per month. ${ }^{11}$ These workers walked off the job after the mining company (Lonmin Platinum) management failed to meet with the workers. A series of violence then followed leading to the massacre that occurred on 16 August when at least thirty six miners were killed and seventy eight wounded by members of the South African Police Service (SAPS). ${ }^{12}$

For communities around the platinum mines as has been well documented in a number of studies by the Bench Marks Foundation, ${ }^{13}$ life is harsh. The majority of the people in these communities live in tiny houses or shacks, with no access to clean water or decent sanitization. According to the Bench Marks Foundation, the water sources surrounding

4 See State Intervention in the Minerals Sector, ANC Policy Discussion Document 2012 available at http://cdn.bdlive.co.za/images/pdf /ANCMineralsdisc.pdf, accessed on 12 January 2013.

5 See, "China, Ghana gold production spike, others fall" available at http://www.mining.com/world-gold-production-2012-preliminaryresults-71758/, accessed on 16 February 2013. South Africa was the world's largest gold producer until 2007 when China became the largest producer of gold. China continued to increase gold production (extraction) and remained the leading gold-producing nation in 2009, followed by Australia.

6 See Platinum Today, available at http://www.platinum.matthey.com/about-pgm/production, accessed on 12 March 2013.

7 See "What South Africa Means To The Platinum Market" accessed on 10 March 2013 available at http://commodityhq.com/2012 /what-south-africa-means-to-the-platinum-market/

8 See National Accounts, Statistics South Africa, available at http://www.statssa.gov.za/publications/D04052/ D040522008.pdf, accessed on 10 January 2013.

$9 \mathrm{lbid}$.

10 See National Accounts, Statistics South Africa, available at http://www.statssa.gov.za/publications/D04052/ D040522008.pdf, accessed on 10 January 2013.

11 See, "Echoes of the past: Marikana, cheap labour and the 1946 miners strike" accessed on 11 October 2013, available at http://libcom.org/files/Echoes\%20of\%20the\%20past\%20Marikana,\%

20cheap\%20labour\%20and\%20the\%201946\%20miners\%20strike.pdf

12 De Vos P, "Some Thoughts on the Marikana Massacre," accessed on 25 September 2012, available at http://constitutionallyspeaking.co.za/some-thoughts-on-the-marikana-massacre.

13 See the following studies: The Bench Marks Foundation, "A Review of the Corporate Social Responsibility Programmes of the Platinum Industry in the North West Province," (2007); "Review of the Corporate Social Responsibility Programmes of the Platinum, Coal, Gold and Uranium Mining Sectors in South Africa," (2008); "A Review of Platinum Mining in the Bojanela District of the North West Province" (2012) - all available at http://www.bench-marks.org.za, accessed on 10 September 2012. 
the townships and informal settlements are often heavily polluted partly from the mining activities. ${ }^{14}$ In this regard, it would not be an overstatement that the Marikana miners' strike was fuelled by the fact that while most mineworkers lived in appalling conditions in informal settlements around the mine, the companies were making huge profits and serving the interests of shareholders while turning a blind eye to the concerns of the mine workers and the Marikana community in which the mining activities took place. Mine workers felt exploited and this was a motivation for the violence. ${ }^{15}$ They were huge frustrations among workers, from whose perspective the mining industry and employers continue to become rich, while they sweat underground, face death on a daily basis and sink deeper into poverty. ${ }^{16}$

Furthermore, the few services that are provided by the mining companies through corporate social responsibility programmes are reported to be mostly of an appalling standard. ${ }^{17}$ According to the Bench Marks Foundation report, the corporate social responsibility programmes in the platinum belt are "top-down, designed by experts and imposed on communities and there is very little evidence that communities, as stakeholders, are actually consulted about their needs, or about their frustrations concerning the impact of mining operations on their lives." 18 The Bench Marks Foundation criticized the high profits when compared with the low wages of the workers. According to the Bench Marks Foundation the benefits of mining are not reaching the workers or the surrounding communities. ${ }^{19}$

\section{Thematic Lessons from the Marikana Miners' Strike}

The Marikana miners' strike has had a significant impact on the corporate governance landscape in South Africa. Perhaps one of the biggest ramifications of the massacre, aside from the tragic deaths of so many, is the revelation of the shortcomings of shareholder value oriented corporate governance. The strike also highlighted the need for stakeholder oriented corporate governance. The ensuing discussion highlights, from a corporate governance perspective, thematic lessons extracted from the Marikana miners' strike.

\subsection{Employees Should be Viewed as Key Stakeholders}

Employees, like shareholders, contribute to the corporation. Shareholders contribute financial capital and employees contribute "skill, time and effort"(or human capital). ${ }^{20}$ Given that both groups are investors in a company, and if we are to accept the premise of the stakeholder approach that each group of stakeholders merits consideration for its own sake, then there is perhaps a strong argument to be advanced for the equal treatment of employees and shareholders. Many benefits accrue in a situation where the interests of employees are considered in corporate governance and there is employee involvement. ${ }^{21}$ For instance, by giving due consideration to the interests of employees in corporate governance, directors may help guarantee a company's long-term profitability and survival. ${ }^{22} \mathrm{~A}$ company's potential to be more profitable would be enhanced as trust ${ }^{23}$ between the company and the employees will induce employees to take steps against their short-term self-interest in order to secure the long term future of the company, and therefore, their job security.

\subsection{Directors' Decisions Should be Cost Effective in the Economic, Social and Environmental context}

Cost and revenue appears to be crucial or central elements of business. Hence liquidity, profitability and solvency are key accounting elements that usually say aloud about the future economic status of a company and reach to the point of

\footnotetext{
${ }^{14}$ The Bench Marks Foundation, "Communities in the Platinum Fields" available at http://www.bench-marks.org.za/research/rustenburg _review_policy_gap_final_aug_2012.pdf accessed on 10 September 2012.

$15 \mathrm{lbid}$.

${ }^{16}$ Coleman N, "More Questions Than Answers," Mail and Guardian, 26 October - 1 November 2012.

17 The Bench Marks Foundation, "Communities in the Platinum Fields" available at http://www.bench-marks.org.za/research/rustenburg _review_policy_gap_final_aug_2012.pdf accessed on 10 September 2012.

${ }_{18} \mathrm{lbid}$.

${ }^{19}$ See - The Bench Marks Foundation, "Communities in the Platinum Fields" available at http://www.bench-marks.org.za/research /rustenburg_review_policy_gap_final_aug_2012.pdf, accessed on 10 September 2012.

20 Greenfield K, "The Place of Workers in Corporate Law" (1998) 39 B.C.L. Rev. 283.

${ }^{21}$ Lutter M, "The German System of Worker Participation in Practice" (1982) Journal of Business Law 154.

22 Ibid.

${ }^{23}$ See Blair MM and Stout LA, "Trust, trustworthiness and the Behavioural Foundations of Corporate Law," (2001) 149 U.PA.L.Rev 1735 1809 - these authors suggest that there is reason to believe that trust plays an important role in the success of many companies.
} 
understanding as to whether a company would meet the expectations of its shareholders. The key element of shareholders' expectations is to earn significant amount of profit or net income from their investments thereby increasing their wealth. Their expectation is legally valid and ethically justifiable as they injected capital into the company with the aspirations of profit. However, while the moral legitimacy of the claim that shareholders have certain expectations because of their investments is accepted, the same basic claim should be extended to all those who invest in the company inter alia employees, creditors, customers and the community. Prioritizing the interests of shareholders while prejudicing the interests of other stakeholders virtually undermines the status of the shareholders as unsatisfied stakeholders may begin disassociating with the company in achieving its corporate goals resulting in the loss of sustainable competence. In this regard, it is recommended that as companies now operate in the triple context which demands focus not only on profits but also on people and the planet, directors should make decisions which are cost effective in the economic, social and environmental context.

\subsection{Directors Should Make Stakeholder Oriented Decisions}

Good corporate citizenship requires that directors make stakeholder oriented decisions. By this is meant that the board should take account of and respond to the legitimate interests and expectations of stakeholders linked to the company in its decision-making. Although it may be virtually difficult or impossible to satisfy all stakeholders to the extent of their expectations, directors must trade off their choices so that potential disappointments on the part of any stakeholder would not arise or at least each stakeholder may be convinced on the choices of directors' decisions by understanding directors' realistic inability to satisfy their hundred percent expectations. Due to the fact that corporate reputations are formed out of the aggregate perceptions of stakeholders' assessments of the companies, stakeholder oriented decisions have the potential to penetrate the investors' confidence.

\subsection{Directors Should Give Due Regard to Sustainability Considerations}

Companies cannot operate in an economically viable manner over a prolonged period without due regard for long-term sustainability issues. When making decisions, directors should therefore, ensure that the needs of the present are met without compromising the ability of the future generations to meet their needs. Hence the success of the company should be viewed in terms of lasting positive impacts for business, society and the environment. Sustainability is one of the principles for good business and corporate governance that maintains the balance between capitalism and greed in relation to the impact of business decisions on economic, social and environmental issues in communities world-wide.

\subsection{Directors Should Carry Out Human Rights Impact Assessments}

Good corporate citizenship inter alia dictates that companies should comply with their human rights responsibilities. To this end, the board should carry out human rights impact assessments before making a decision and after carrying out the objectives of the decision. The process entails assessing actual and potential human rights impacts, acting upon the findings and communicating how impacts are addressed. Human rights impact assessment should be an on-going exercise, recognizing that human rights risks may change over time as the company's operations and operating context evolve. Companies should have processes in place to enable remediation in situations where a human rights impact assessment or other means reveal that the company has caused or contributed to an adverse impact.

\subsection{Directors Should Carry Out Environmental Impact Assessments}

The board should carry out environmental impact assessments before making a decision and after carrying out the objectives of the decision. An environmental impact assessment is a pro-active and systematic process where potential environmental impacts both positive and negative associated with certain activities of a company are assessed, investigated and reported. The process contributes to giving effect to the objectives of integrated environmental management as decision makers are informed of the desirability of such activities and on the conditions which authorization of the activity should be subjected to, where relevant. 


\subsection{Companies Need to Address Workers' Economic/Financial Illiteracy}

Given the harsh conditions facing mining workers as highlighted, it is beyond dispute that they are justified in demanding higher wages. However, while that is the case, demands for higher wages should take into account the economic climate, as companies in sectors that are struggling due to the weak economic growth environment may only be able to afford inflation-linked wage increases. The failure to understand the economic reality that some companies in certain sectors may only be able to afford inflation-linked wage increases means workers will make and continue making unrealistic wage demands because they believe it is attainable. The unfortunate effect is that where settlements are above what the economy can afford, there could be job losses. An understanding of the economic context within which their companies operates would therefore, better inform the wage demands of workers.

\section{Conclusion}

While mining companies are important and powerful players in today's world, mining activities often leave irreversible social, economic and environmental impacts on various stakeholders such as for example the communities in which mining activities takes place. In this regard, companies should therefore be socially responsible. Companies are an integral part of society and they have a clear stake in ensuring that workers for example are inter alia treated properly, receive fair and equitable wages and work under safe conditions. The downside of no or inadequate social responsibility is not increased costs or reduced profits but legal liability. Companies can no longer get away with social irresponsibility. There is thus need for directors to assess the impact of their actions on those whom their business affects and endeavor to minimize harm and do what good they can. As this is achieved, the company earns the necessary approval, its licence to operate, from those affected by and affecting its operations.

\section{References}

Alexander P, Lekgowa T, Mmope B, Sinwell L and Xeswi B, Marikana: A View from the Mountain and a Case to Answer (2012) Jacana Media.

Alexander P, Lekgowa T, Mmope B, Sinwell L and Xeswi B, Marikana: Voices from South Africa's Mining Massacre (2013) Ohio University Press.

Davies D, Cassim F, Geach W, Mongalo T, Butler D, Loubser A, Coetzee L and Burdett D, Companies and Other Business Structures in South Africa $2^{\text {nd }}$ Edition (2011) Oxford University Press Southern Africa.

Hendrikse JW and Hefer-Hendrikse L Corporate Governance Handbook 2nd Edition 2004 Juta\& Co. Ltd.

Seccombe A, "Amplants bows to State Pressure in Retrenchment Talks" available at http://www.bdlive.co.za/business/mining/2013/01 /29/amplats-bows-to-state-pressure-in-retrench ment-talks, accessed on 12 February 2013.

Statistics South Africa, available at http://www.stassa.gov.za/keyindicators/ GDP/GPP_1stQuarter2013_Press_Statement.pdf accessed on 10 June 2013

Tapula T, "Making the Mining Charter Go Further Towards Genuine Empowerment" available at http://www.saiia.org.za/opinionanalysis/making-the-mining-charter-go-further-towards-genuine-empowerment, accessed on 29 December 2012.

The Bench Marks Foundation, "Communities in the Platinum Fields" available at http://www.bench-marks.org.za/research/rustenburg review_policy_gap final_aug_2012.pdf, accessed on 10 September 2012.

Colemān N, "More Questions Thän Answers," Mail and Guardian, 26 October - 1 November 2012.

Corporate Watch, "Blood Money, Shock Revelations and Media Half-Truths on South African Mine Violations" (2013) available at http://www.corporatewatch.org/?lid=4741, accessed on 25 March 2013.

ILO news, available at http://www.ilo.org/global/about-the-lo/newsroom/news/WCMS_187783/lang--en/index.htm, accessed on 22 January 2013.

De Vos P, "Some Thoughts on the Marikana Massacre," available at http://constitutionallyspeaking.co.za/some-thoughts-on-themarikana-massacre

accessed on 25 September 2012. 
